Vol. 20(2011): 315-326.

\title{
The effect of different tillage-fertilization practices on the mycoflora of wheat grains
}

\author{
Skaidre Suproniene*, Audrone Mankeviciene, Grazina Kadziene, Dalia Feiziene, Virginijus Feiza, Roma \\ Semaskiene and Zenonas Dabkevicius \\ Institute of Agriculture, Lithuanian Research Centre for Agriculture and Forestry, Instituto al. 1, Akademija, LT- \\ 58344, Kédainiai distr., Lithuania \\ e-mail: skaidre@lzi.lt
}

\begin{abstract}
A two-factor field experiment was carried out at the Lithuanian Institute of Agriculture during the period 2005-2008. The influence of different tillage and fertilization practices on wheat grain fungal contamination was evaluated. Grain surface contamination and internal grain infection with fungi were quantified using agar tests. Purified colonies were identified using different manuals. A total of 16 fungal genera were identified in spring and winter wheat grains. Alternaria infected $46.3 \%-99.9 \%$, Cladosporium $26.9 \%-$ $77.8 \%$, Fusarium $0.9 \%-37.1 \%$, Penicillium $1.3 \%-2.5 \%$ of grains tested. Winter wheat grain surface contamination by fungi ranged from $7.2 \times 10^{3}$ to $24.8 \times 10^{3}$ of colony forming units per $\mathrm{g}$ of grain $\left(\mathrm{cfu} \mathrm{g}^{-1}\right)$, spring wheat from $14.8 \times 10^{3}$ to $80.3 \times 10^{3} \mathrm{cfu}^{-1}$. No-tillage increased winter wheat grain infection by Alternaria, Aspergillus and Cladosporium species and total count of $\mathrm{cfu}^{-1}$ on spring wheat grain surface. High fertilizer rates resulted in an increase in spring wheat grain infection by Fusarium and Penicillium species and total count of $\mathrm{cfu}^{-1}$ on both spring and winter wheat grain surface.
\end{abstract}

Key words: contamination, fungi, fertilization, grain, tillage, wheat

\section{Introduction}

Wheat (Triticum aestivum L.) is one of the most important cereal crops and a staple food worldwide. In Lithuania, winter wheat prevails and occupies more farmland than any other crop. The production area of spring wheat has increased over the recent years, too.

Mouldboard ploughing is a common tillage system in Lithuania; however, direct drilling and other conservation tillage practices are becoming increasingly popular, especially on the more fertile soils of the central part of the country. Reduced tillage has an advantage over the conventional tillage, because of reduced costs (Ribera et al. 2004, Yalcin et al. 2005, Feizienè et al. 2006) and given environmental benefits: reduction in soil erosion, nitrate leaching, fuel use, increasing soil organic matter and activity of soil organisms, improving soil structure and preserving soil moisture (Roldán et al. 2004, Subbulakshmi et al. 2009, Feiza et al. 2010, Bogužas et al. 2010). Nevertheless, no-tillage may result in increased propagule densities of 
Suproniene, S. et al. Tillage and fertilization effect on grain mycoflora

most of the fungi present in the soil, including plant pathogens such as Rhizoctonia spp. and Pythium spp. (Ploetz et al. 1985). Field experiments verified that non-inversion tillage is a major factor increasing the severity of tan spot (Pyrenophora tritici-repentis) (Jørgensen and Olsen 2007), Septoria leaf blotch (Septoria tritici) (Bailey and Duczek 1995), Stagonospora leaf blotch (Stagonospora avenae) (Elen 2003) compared with conventional ploughing. It may also result in increased Fusarium head blight (FHB) incidence and severity (Dill-Macky and Jones 2000, Fernandez et al. 2005, Lori et al. 2009).

Crop residues left on or near the soil surface in reduced tillage may be a source of inoculum not only for pathogens, but also for a wide range of fungi which may develop on grains and present a potential threat to their quality. Clear and Patrick (1993) indicated at least 59 species representing 35 fungal genera on soft white winter wheat seed from Ontario. Lõiveke et al. (2004) identified 63 fungi species on Estonian spring and winter wheat grains and grain feeds during 1992-1994. Alternaria, Cladosporium, Fusarium, Aspergillus, Penicillium were among the main species identified on wheat grains (Clear and Patrick 1993, Lõiveke et al. 2004, Rajput et al. 2005, Semaškienė et al. 2005, Bakutis et al. 2006, Gohari et al. 2007). Alternaria and Cladosporium are one of the most common species on grains; they are harmless saprophytes of cereals. Some Alternaria species are (opportunistic) plant pathogens that, collectively, cause a range of diseases with economic impact on a large variety of important agronomic host plants including cereals, also well known as post-harvest pathogens (Thomma 2003). Under certain conditions they may produce mycotoxins such us tenuazonic acid, alternariols and others (Scudamore, 2000). Fusarium species are destructive pathogens on cereal crops and produce mycotoxins before, or immediately after, harvest (D'Mello et al. 1999, Bottalico and Perrone, 2002, Thrane et al. 2004). Certain species of Aspergillus and Penicillium are also plant pathogens, but they are more commonly associated with grain storage (Pitt 2000). Penicillium chrysogenum, Aspergillus flavus and Rhizopus chizopodifarmis may decrease dry matter digestibility, amino acid, vitamin and fat contents in feed during storage (Maciorowski et al. 2007). Aspergillus, Fusarium and Penicillium are the main mycotoxin producers in cereal grains. The most significant mycotoxins in naturally - contaminated foods and feeds are aflatoxins, ochratoxins, zearalenone, T-2 toxin, deoxynivalenol and fumonisins (Surai and Mezes, 2005) produced by the above mentioned fungal species. Mycotoxins, when ingested, may cause a mycotoxicosis which can result in an acute or chronic disease episode (Bryden, 2007). Alternaria, Cladosporium, Aspergillus and Penicillium also are known as air -born allergens causing rhinitis and severe asthma (Breitenbach and SimonNobbe 2002, Gomez de Ana et al. 2006). As was shown by Kačergius et al. (2005) the same fungi (Aspergillus, Fusarium, Penicillium, Alternaria and Rhizomucor) which infected grain, vegetable and fruit were also predominant in the air of their storehouses.

Development of fungal infection in cereals has been associated primarily with environmental conditions. Clear and Patrick (1993) recorded yearly differences in the quantity and time of precipitation and the frequency of a number of fungal species (Bipolaris sorokiniana, Pyrenophora triticirepentis, and Septoria nodorum), including a 100 fold increase in the frequency of $F$. graminearum between 1988 and 1989 in Ontario. In Lithuania, Semaškienè et al. (2005) indicated that host-plant, cultivar and weather conditions influenced organic grain fungal infection level. A survey of the fungal contamination of wheat and barley grains grown in organic and conventional farms was done with a focus on mycotoxin producing fungi (Bakutis et al. 2006). The findings evidenced that fungal contamination on wheat grain from organic farms was by $70.5 \%(\mathrm{p}<0.05)$ higher than that on conventionally grown grain.

The effect of conventional and reduced tillage systems on FHB and wheat foliar diseases combined with the other agronomic practices is presented by researches; however the information about this effect on the total fungal contamination of cereal grains is rather scanty; the data about fertilization influence are also limited. There is some evidence that FHB can be affected by fertilizer 
Vol. 20(2011): 315-326.

regimes. Teich (1989) and Martin et al. (1991) observed that increasing the amount of nitrogen $(\mathrm{N})$ applied to cereals resulted in increased incidence of FHB or Fusarium-infected grain. However Lori et al. (2009) reported that favourable weather conditions are more important for FHB infection than tillage practice and fertilizer treatments.

This study was designed to explore the influence of different tillage and fertilization practices on winter and spring wheat grain contamination by fungi, potential cereal pathogens, or other contaminants such as mycotoxin producers or allergens for humans and farm livestock.

\section{Materials and methods}

The study site is located at the Lithuanian Institute of Agriculture (Central part of Lithuania). Studies were carried out on the basis of two long-term field trials, established in the autumn of 1999 (first trial) and 2000 (second trial) on a loamy EndocalcariEpihypogleyic Cambisol. The experimental design was a split plot in four blocks (replications), with the tillage treatments: conventional tillage, reduced tillage and no-tillage as the main plots (Table 1). Fertilization rates of mineral NPK (none, moderate and high), designed as subplots, were calculated according to the soil properties and expected crop yield (Švedas and Tarakanovas 2000). Crop rotation was as follows: winter wheat - spring rape - spring wheat - spring barley - pea in both field experiments. For mycological study we used winter and spring wheat grain samples collected during 2005-2008 (second crop rotation). Because of poor winter wheat over winter survival in 2006, half of the field trial was re-sown with spring wheat (dividing trial plots in two equal parts across all treatments). Therefore in 2006 both winter and spring wheat grain samples were used for assessment. Plant residues of the pre-crops were collected and removed from the experimental field each year after harvest. Using of conventional crop rotation, unfavourable for wheat diseases, we expected to get results influenced only by tillage and fertilization. Each year, 3 weeks after harvesting of previous crop, non-selective herbicide (glyphosate at a dose of $1.44 \mathrm{~kg}$ a.i. $\mathrm{ha}^{-1}$ ) was sprayed in no-tillage plots to control weeds and volunteer plants (cereals or oil seed rape).

Grain samples of $1.0 \mathrm{~kg}$ for laboratory analyses were taken from each plot at harvesting. Subsamples were stored in plastic jars in a freezer at $-20^{\circ} \mathrm{C}$ to prevent alterations in fungi and mycotoxin contents until the conduct of analyses. Before analyzing, the grain was de-frosted up to room temperature. Grain surface contamination was determined using dilution plating method. Ten grams of each sample was suspended in $100 \mathrm{ml}$ of sterile distilled water. A $1 \mathrm{ml}$ sample of this nutrient suspension was used to prepare a dilution series from 1:1000. Dilution was uniformly dispensed under the surface of acidified malt agar (MA: $300 \mathrm{ml}$ of maltose; $13 \mathrm{~g}$ of agar; $1.2 \mathrm{~g}$ of citric acid and 700 $\mathrm{ml}$ of distilled water) in Petri-dishes and incubated for $3-5$ days at $25^{\circ} \mathrm{C}$ in the dark. After incubation, the number of fungal colonies was calculated and expressed in colony - forming units per $g$ of grain (cfu g $\left.{ }^{-1}\right)$.

Plating technique was used for internal fungal grain infection estimation. Surface-sterilized (for 3 minutes in $1 \% \mathrm{NaOCl}$ solution) grains were plated in Petri-dishes with potato dextrose agar (PDA: $250 \mathrm{~g}$ of potato, $10 \mathrm{~g}$ of glucose, $14 \mathrm{~g}$ of agar and 11 of distilled water) and incubated for 7-8 days at $26 \pm 2{ }^{\circ} \mathrm{C}$ (International Rules for Seed Testing 2003). The fungi were identified according to the manuals of Malone and Muskett (1997), Mathur and Kongsdal (2003), Lugauskas et al. (2002), Nelson et al. (1983) and Leslie and Summerell (2006). The grain fungal infection level per sample was expressed in percent.

Significance of the differences between the means was determined according to the least significant difference (LSD) at 0.05 probability level. The data were processed using the software ANOVA, SPIL-PLOT from the package SELEKCIJA (Tarakanovas and Raudonius, 2003). 
Suproniene, S. et al. Tillage and fertilization effect on grain mycoflora

Table 1. Experimental design of different soil tillage-fertilization systems.

\begin{tabular}{lll}
\hline & \multicolumn{2}{c}{ Tillage (factor A) } \\
\hline treatment & primary tillage & pre-sowing tillage \\
\hline conventional tillage & deep ploughing $(23-25 \mathrm{~cm})$ & spring tine cultivation $(4-5 \mathrm{~cm})$ \\
reduced tillage & shallow ploughing $(14-16 \mathrm{~cm})$ & spring tine cultivation $(4-5 \mathrm{~cm})$ \\
no-tillage & no tillage & direct drilling combined with rotary cultivation \\
& & $(2-3 \mathrm{~cm})$ \\
\hline
\end{tabular}

Fertilization (factor B)*

\begin{tabular}{|c|c|}
\hline not fertilized & no fertilization \\
\hline moderate rates & $\begin{array}{l}\text { mineral NPK fertilizers according to soil nutrient status and expected yield (winter } \\
\text { wheat } 6.5 \mathrm{t} \mathrm{ha}^{-1} \text {, spring wheat } 4.5 \mathrm{t} \mathrm{ha}^{-1} \text { ) }\end{array}$ \\
\hline high rates & $\begin{array}{l}\text { mineral NPK fertilizers according to soil nutrient status and expected yield (winter } \\
\text { wheat } 8.0 \mathrm{tha}^{-1} \text {, spring wheat } 6.0 \mathrm{tha}^{-1} \text { ) }\end{array}$ \\
\hline
\end{tabular}

\section{Results}

On winter wheat grain surface, we identified 10 fungal genera in 2005 and 6 fungal genera in 2006 (Table 2). Cladosporium and Penicillium were the most frequent species in the winter wheat grain samples. Isolation frequency of Aspergillus, Fusarium and Mucor species in winter wheat grain samples was higher in 2005 than that in 2006. Acremonium, Arthrinium, Botrytis and Verticillium were identified only in 2005. Isolation frequency of Penicillium species was similar in both years, while Alternaria was more frequent in 2006.

Fungal species of 9-12 genera were identified on spring wheat grain surface. Alternaria, Fusarium and Cladosporium species were detected in all spring wheat grain samples in 2006, Nigrospora and Trichoderma were present only in 2006, however Aspergillus and Pyrenophora only in 2007-2008. Acremonium, Alternaria, Arthrinium, Botrytis and Mucor were less frequent or not detected in 2008. Penicillium and Verticillium were more frequent in 2008 than in 2006-2007.

A total of 14 fungal genera were isolated from winter and spring wheat grain surface. Alternaria,
Cladosporium, Fusarium and Penicillium species were the most common. Cladosporium spp. was identified in all tested samples. Arthrinium, Botrytis, Pyrenophora, Nigrospora, Trichoderma and Ulocladium were less frequent. Acremonium and Alternaria species were more prevalent on spring wheat grain surface than on winter wheat. Pyrenophora, Nigrospora, Trichoderma and Ulocladium were identified only on spring wheat grains.

The fungal contamination of winter wheat grains ranged from $7.2 \times 10^{3}$ to $24.8 \times 10^{3} \mathrm{cfu} \mathrm{g}^{-1}$ (Table 3). Grains were more contaminated in 2005 than 2006. There were no significant differences between tillage practices. However, high and moderate fertilizer rates in 2005 and high rates in 2006 significantly increased grain surface contamination compared to not fertilized winter wheat.

The fungal contamination of spring wheat grains ranged from $14.8 \times 10^{3}$ to $80.3 \times 10^{3} \mathrm{cfu}$ $\mathrm{g}^{-1}$ (Table 4). Grains were more contaminated in 2006, than 2007 and 2008. No-tillage significantly increased spring wheat grain surface contamination in 2006 and 2007. High fertilizer rates increased fungal count only in 2006 and moderate rates in 2008 . 
Vol. 20(2011): 315-326.

Table 2. Fungal species on the surface of wheat grain, 2005-2008.

\begin{tabular}{|c|c|c|c|c|c|}
\hline \multirow[b]{3}{*}{ Fungal species } & \multicolumn{4}{|c|}{ Isolation frequency $(\%)$ in grain samples } & \multirow[b]{3}{*}{2008} \\
\hline & \multicolumn{2}{|c|}{ Winter wheat } & \multicolumn{2}{|c|}{ Spring wheat } & \\
\hline & 2005 & 2006 & 2006 & 2007 & \\
\hline Acremonium & 5.6 & 0.0 & 47.2 & 38.9 & 8.3 \\
\hline Alternaria & 13.9 & 33.3 & 100.0 & 97.2 & 83.3 \\
\hline Aspergillus & 94.4 & 2.8 & 0.0 & 47.2 & 25.0 \\
\hline Arthrinium & 2.8 & 0.0 & 2.8 & 8.3 & 0.0 \\
\hline Botrytis & 5.6 & 0.0 & 2.8 & 2.8 & 0.0 \\
\hline Cladosporium & 100.0 & 100.0 & 100.0 & 100.0 & 100.0 \\
\hline Pyrenophora & 0.0 & 0.0 & 0.0 & 8.3 & 5.6 \\
\hline Fusarium & 91.7 & 55.6 & 100.0 & 86.1 & 86.1 \\
\hline Mucor & 44.4 & 2.8 & 13.9 & 5.6 & 0.0 \\
\hline Nigrospora & 0.0 & 0.0 & 8.3 & 0.0 & 0.0 \\
\hline Penicillium & 94.4 & 97.2 & 69.4 & 72.2 & 83.3 \\
\hline Trichoderma & 0.0 & 0.0 & 2.8 & 0.0 & 0.0 \\
\hline Ulocladium & 0.0 & 0.0 & 2.8 & 0.0 & 2.8 \\
\hline Verticillium & 5.6 & 0.0 & 11.1 & 0.0 & 22.2 \\
\hline
\end{tabular}

Table 3. The fungal contamination of winter wheat grain as influenced by different tillage- fertilization treatments, 2005-2006.

\begin{tabular}{|c|c|c|c|c|}
\hline \multicolumn{4}{|c|}{ Fertilization (factor B) } & \multirow{2}{*}{$\begin{array}{l}\text { Average } A \\
\left(\mathrm{~F}_{\text {act }} \text { n.s. }\right)\end{array}$} \\
\hline Tillage (factor A) & not fertilized & moderate rates & high rates & \\
\hline \multicolumn{5}{|c|}{ Grain surface contamination by fungi, cfu g ${ }^{-1} \times 10^{3}, 2005$} \\
\hline conventional & 13.8 & $24.6^{*}$ & $27.0 * *$ & 21.0 \\
\hline reduced & 19.9 & 18.5 & 17.6 & 18.7 \\
\hline no-tillage & 16.3 & 22.6 & 21.0 & 19.6 \\
\hline Average $B\left(\mathrm{~F}_{\mathrm{act}} *\right)$ & 16.6 & $21.5^{*}$ & $21.9 *$ & \\
\hline \multicolumn{5}{|c|}{ Grain surface contamination by fungi, cfu g ${ }^{-1} \times 10^{3}, 2006$} \\
\hline conventional & 7.2 & 9.5 & $15.8 * *$ & 10.8 \\
\hline reduced & 11.0 & $12.5^{*}$ & $13.6^{* *}$ & 12.4 \\
\hline no-tillage & 8.7 & $11.8 *$ & $11.5^{*}$ & 10.7 \\
\hline Average $B\left(\mathrm{~F}_{\text {act }} * *\right)$ & 8.9 & 11.3 & $13.6^{* *}$ & \\
\hline
\end{tabular}


Suproniene, S. et al. Tillage and fertilization effect on grain mycoflora

Table 4. The fungal contamination of spring wheat grain as influenced by different tillage- fertilization treatments, 2006-2008.

\begin{tabular}{|c|c|c|c|c|}
\hline \multicolumn{5}{|c|}{ Fertilization (factor B) } \\
\hline Tillage (factor A) & not fertilized & moderate rates & high rates & \multirow{2}{*}{$\begin{array}{l}\text { Average } A \\
\left(\mathrm{~F}_{\text {act }} *\right)\end{array}$} \\
\hline \multicolumn{4}{|c|}{ Grain surface contamination by fungi, cfu g ${ }^{-1} \times 10^{3}, 2006$} & \\
\hline conventional & 43.2 & 38.0 & $63.9 *$ & 48.4 \\
\hline reduced & 35.9 & 54.4 & 58.3 & 49.5 \\
\hline no-tillage & 49.3 & 59.1 & $80.3 * *$ & $62.9^{*}$ \\
\hline \multirow[t]{2}{*}{ Average $B\left(\mathrm{~F}_{\text {act }} * *\right)$} & 42.8 & 50.5 & $67.5 * *$ & \\
\hline & \multicolumn{3}{|c|}{ Grain surface contamination by fungi, $\mathrm{cfu} \mathrm{g}^{-1} \times 10^{3}, 2007$} & $\left(\mathrm{~F}_{\mathrm{act}} *\right)$ \\
\hline conventional & 18.6 & 14.8 & 18.3 & 17.2 \\
\hline reduced & 16.5 & 19.9 & 19.3 & 18.5 \\
\hline no-tillage & $33.9 *$ & 31.1 & 16.0 & $27.0^{*}$ \\
\hline \multirow[t]{2}{*}{ Average $B\left(\mathrm{~F}_{\text {act }}\right.$ n.s. $)$} & 23,0 & 21.9 & 17.8 & \\
\hline & \multicolumn{3}{|c|}{ Grain surface contamination by fungi, $\mathrm{cfu} \mathrm{g}^{-1} \times 10^{3}, 2008$} & $\left(\mathrm{~F}_{\text {act }}\right.$ n.s. $)$ \\
\hline conventional & 24.1 & $30.7^{*}$ & 28.7 & 27.8 \\
\hline reduced & 22.6 & 29.7 & 25.1 & 25.8 \\
\hline no-tillage & 25.1 & 27.3 & 26.9 & 26.4 \\
\hline Average $B\left(\mathrm{~F}_{\mathrm{act}} *\right)$ & 23.9 & $29.2^{*}$ & 26.9 & \\
\hline
\end{tabular}

Cladosporium colony accounted for nearly half of the total fungal colonies formed. As a result, the increase in the total number of colony forming units $\left(\mathrm{cfu} \mathrm{g}^{-1}\right)$ in some cases depended on the increase in the count of Cladosporium colonies. A multifactor analysis of variance demonstrated a significant effect of fertilization on the total count of $\mathrm{cfu} \mathrm{g}^{-1}$ and on that of Cladosporium spp. in 2005-2006. Without Cladosporium colonies taken into account, fertilization had a significant effect on the fungal count only in spring wheat in 2006 (Table 5). Conversely, a significant tillage effect was established on the amount of the other fungal colonies than Cladosporium on spring wheat grain surface.

A total of 15 fungal genera were detected in surface sterilized wheat grains (Table 6). Internal tissues of wheat kernels were infected mainly by the same fungal species as those found on the grain surface, except for Acremoniella and Gonatobotrys, which occurred in $0.1 \%-5.3 \%$ and in $1.4 \%$
- $14.3 \%$ of spring wheat grains, respectively. $A l$ ternaria spp. (mostly $A$. alternata) was the most frequently detected species in the internal tissues of wheat grains, occurring in $46.3 \%-96.5 \%$ of winter wheat and in nearly $100 \%$ of spring wheat grains. Aspergillus spp. occurred in 3.3\% (in 2005) and in 2.5-3.9\% (in 2007-2008), Cladosporium spp. in $26.9 \%-63.6 \%$ and in $35.6 \%-77.8 \%$ of winter and spring wheat grains, respectively. Pyrenophora spp. infected $1.1 \%$ of winter wheat grains in 2005 and $0.3-4.4 \%$ of spring wheat grains in 2007-2008. Fusarium spp. were detected in $0.9 \%$ $-4.7 \%$ of winter wheat and in $32.8 \%-37.1 \%$ of spring wheat grains. Penicillium spp. infected about $2 \%(1.3-2.5)$ of winter wheat and from $1.6 \%$ to $11.2 \%$ of spring wheat grains. The other fungi (Acremonium, Arthrinium, Botrytis, Mucor, Nigrospora, Trichoderma and Verticillium) occurred only sporadically and at negligible levels (from $0.1 \%$ to $5.3 \%$ ). 
Vol. 20(2011): 315-326.

Table 5. Analysis of variance $p$ values from grain-testing the total count of fungal colony forming units ( $\mathrm{cfu}^{-1}$ ), Cladosporium spp. and other fungal colony forming units $\left(\mathrm{cfu}^{-1}\right)$ from wheat grain surface, 2005-2008.

\begin{tabular}{|c|c|c|c|c|c|}
\hline \multicolumn{6}{|c|}{ ANOVA $p$ values } \\
\hline \multicolumn{3}{|c|}{ Winter wheat grains } & \multicolumn{3}{|c|}{ Spring wheat grains } \\
\hline Source of variation & 2005 & 2006 & 2006 & 2007 & 2008 \\
\hline \multicolumn{6}{|c|}{ Total fungal colony forming units, cfu $\mathrm{g}^{-1}$} \\
\hline Tillage (A) & 0.3120 & 0.3606 & 0.0061 & 0.0468 & 0.4794 \\
\hline Fertilization (B) & 0.0303 & 0.0050 & 0.0001 & 0.4117 & 0.0160 \\
\hline $\mathrm{A} \times \mathrm{B}$ & 0.0548 & 0.1948 & 0.1903 & 0.2044 & 0.7020 \\
\hline \multicolumn{6}{|c|}{ Cladosporium colony forming units, $\mathrm{cfu} \mathrm{g}^{-1}$} \\
\hline Tillage (A) & 0.0151 & 0.1877 & 0.0587 & 0.1498 & 0.1573 \\
\hline Fertilization (B) & 0.0116 & 0.0320 & 0.0024 & 0.5931 & 0.6516 \\
\hline $\mathrm{A} \times \mathrm{B}$ & 0.0237 & 0.2531 & 0.4862 & 0.0944 & 0.1882 \\
\hline \multicolumn{6}{|c|}{ Other fungal colony forming units (without Cladosporium), $\mathrm{cfu} \mathrm{g}^{-1}$} \\
\hline Tillage (A) & 0.8238 & 0.0832 & 0.0165 & 0.0004 & 0.0338 \\
\hline Fertilization (B) & 0.1652 & 0.3995 & 0.0003 & 0.0926 & 0.0610 \\
\hline$A \times B$ & 0.5882 & 0.8502 & 0.0159 & 0.0018 & 0.5467 \\
\hline
\end{tabular}

Table 6. Fungal infection level of wheat grain, 2005-2008.

\begin{tabular}{lccccc}
\hline \multicolumn{5}{c}{ Percentage of grains infected with the fungal species listed \pm SD. } \\
\hline Fungal species & Winter wheat & \multicolumn{5}{c}{ Spring wheat } \\
\hline Acremoniella & 2005 & 2006 & 2006 & 2007 & 2008 \\
Acremonium & 0.0 & 0.0 & $5.3 \pm 5.4$ & 0.0 & $0.1 \pm 0.3$ \\
Alternaria & 0.0 & $5.3 \pm 5.4$ & $0.7 \pm 1.2$ & $0.2 \pm 0.3$ & 0.0 \\
Aspergillus & $96.5 \pm 2.3$ & $46.3 \pm 10.8$ & $98.1 \pm 0.9$ & $99.9 \pm 0.3$ & $99.2 \pm 0.8$ \\
Arthrinium & $3.3 \pm 3.1$ & 0.0 & 0.0 & $2.5 \pm 1.8$ & $3.9 \pm 2.3$ \\
Botrytis & $0.5 \pm 0.6$ & $0.2 \pm 0.4$ & $0.3 \pm 0.5$ & 0.0 & $0.1 \pm 0.3$ \\
Cladosporium & $1.5 \pm 0.9$ & $0.1 \pm 0.3$ & 0.0 & 0.0 & $0.1 \pm 0.3$ \\
Pyrenophora & $63.3 \pm 9.4$ & $26.9 \pm 7.9$ & $77.8 \pm 4.5$ & $35.6 \pm 4.1$ & $36.9 \pm 17.9$ \\
Fusarium & $1.1 \pm 1.9$ & 0.0 & 0.0 & $0.3 \pm 0.4$ & $4.4 \pm 3.3$ \\
Gonatobotrys & $4.7 \pm 3.2$ & $0.9 \pm 0.8$ & $37.1 \pm 4.7$ & $32.8 \pm 7.9$ & $34.7 \pm 5.7$ \\
Mucor & 0.0 & 0.0 & $1.4 \pm 1.6$ & $14.3 \pm 2.8$ & $2.2 \pm 1.3$ \\
Nigrospora & $1.0 \pm 1.2$ & $0.7 \pm 0.8$ & 0.0 & $0.1 \pm 0.3$ & 0.0 \\
Penicillium & $0.2 \pm 0.6$ & $0.4 \pm 0.6$ & 0.0 & 0.0 & 0.0 \\
Trichoderma & $2.5 \pm 1.1$ & $1.3 \pm 1.6$ & $11.2 \pm 4.9$ & $1.6 \pm 1.4$ & $2.0 \pm 1.6$ \\
Verticillium & 0.0 & $0.3 \pm 0.8$ & $1.4 \pm 2.8$ & 0.0 & $0.1 \pm 0.3$ \\
\hline
\end{tabular}


Suproniene, S. et al. Tillage and fertilization effect on grain mycoflora

Agricultural practices used in this experiment showed some influence on individual fungi and differed between years and seasonal type of wheat (spring or winter). With no-tillage practice, we observed a significant increase in winter wheat grain infection with Alternaria spp. in both years $\left(\mathrm{F}_{\text {act }}{ }^{*}, p\right.$ $\left.=0.0474,2005 ; \mathrm{F}_{\mathrm{act}}{ }^{* *}, p=0.0018,2006\right)$, Aspergillus spp. in $2005\left(\mathrm{~F}_{\text {act }}^{*}, p=0.0278\right)$ and Cladosporium spp. in $2006\left(\mathrm{~F}_{\text {act }}^{* *}, p=0.0076\right)$ (Fig. 1).

High fertilizer rates significantly increased spring wheat grain infection with Penicillium spp. in $2006\left(\mathrm{~F}_{\text {act }}^{* *}, p=0.0044\right)$ and Fusarium spp. in $2007\left(\mathrm{~F}_{\text {act }} * *, p=0.0047\right)$ as shown in Figure 2.

\section{Discussion}

Fungal species belonging to 16 genera were identified in spring and winter wheat grains during 2005-2008. Very similar fungal complexes devel- oped on the surface and in the internal tissues of grains. Alternaria, Cladosporium, Fusarium and Penicillium were the most frequent in grain samples: Alternaria 46.3\% - 99.9\%, Cladosporium 26.9\%$77.8 \%$, Fusarium $0.9 \%$ - 37.1\%, Penicillium $1.3 \%$ - 2.5\%. Isolation frequency of Aspergillus varied more among years (from 0 to 94.4) compared with that of the above mentioned fungi and, depending on the year, infected grain accounted for from 0 to $3.9 \%$ of the grain tested. All these fungi have been previously reported as prevalent in wheat grains (Clear and Patrick 1993, Lõiveke et al. 2004, Rajput et al. 2005, Semaškienè et al. 2005, Bakutis et al. 2006, Gohari et al. 2007).

Most of the identified fungi normally exist as saprophytes or weak plant pathogens. While Fusarium species is mainly associated with FHB, one of most important fungal diseases of wheat in all cropping areas worldwide, which reduce yield, seed quality and causes mycotoxin production in grain (Botalico et al. 1989, Tuite et al. 1990, Argyris et al. 2003). The Alternaria, Fusarium, Peni-
Figure 1. The influence of no-tillage on winter wheat grain infection with Alternaria, Aspergillus and Cladosporium fungi in 2005-2006.

Figure 2. The influence of high fertilizer rates on spring wheat grain infection with Fusarium and Penicillium fungi in 2006-2007.
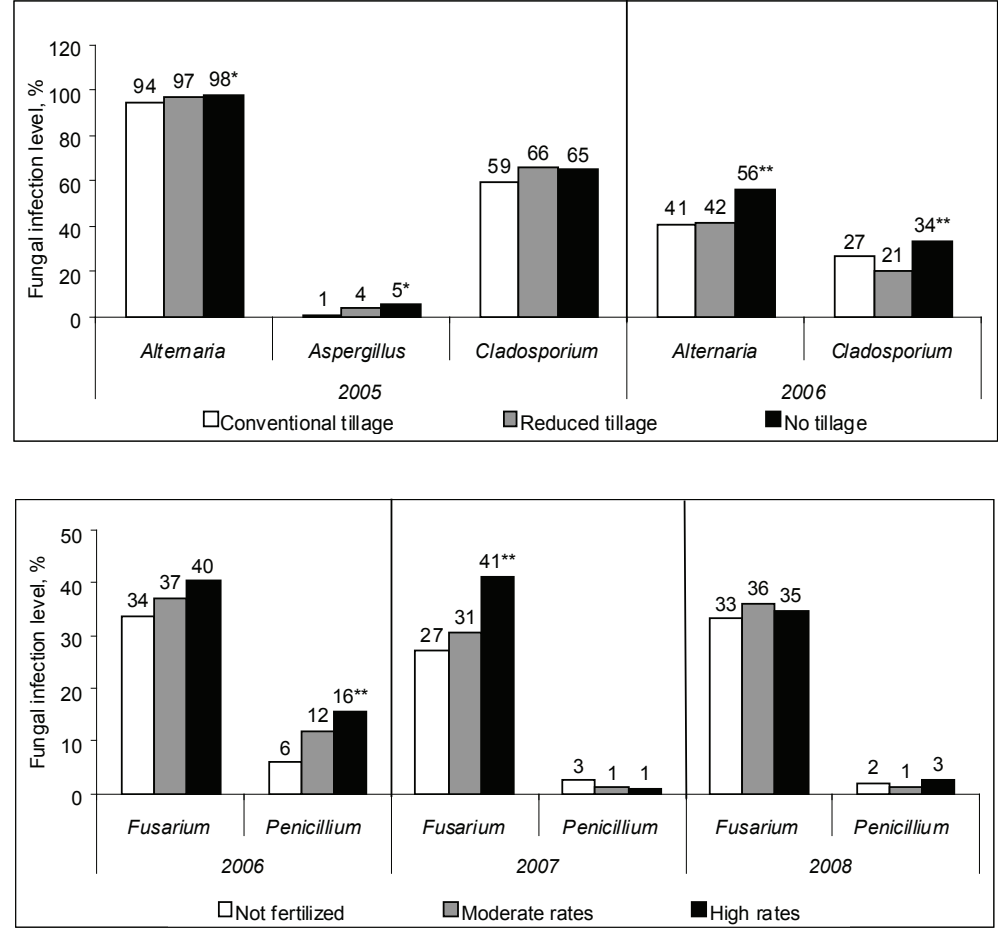
Vol. 20(2011): 315-326.

cillium and Aspergillus species may decrease seed germination, induce seed discoloration, chemical and nutritional changes, and form mycotoxins, that constitute a health hazard for humans and animals, under both field and storage conditions (Sauer 1988, Pitt 2000, Bryden 2007, Maciorowski et al. 2007, Malaker et al. 2008).

Our results indicated that spring wheat grain samples had fungal counts higher $\left(14.8 \times 10^{3}-\right.$ $\left.80.3 \times 10^{3} \mathrm{cfu} \mathrm{g}^{-1}\right)$ than winter wheat grain samples $\left(7.2 \times 10^{3}\right.$ to $\left.24.8 \times 10^{3} \mathrm{cfu} \mathrm{g}^{-1}\right)$ as well as Fusarium infection level: $32.8 \%-37.1 \%$ and $0.9 \%-4.7 \%$, respectively. Similar differences in the Fusarium infection level between winter and spring cereals in Lithuania were reported in previous researches (Semaškienė et al. 2005, Suproniene et al. 2010). The obtained results also agree with those obtained by Kosiak et al. (2007). This might have resulted from some environmental factors: meteorological conditions, time and length of flowering period and source of infection (Suproniene et al. 2010). Yearly differences in fungal counts and infection levels were also indicated during this study, which is in accordance with other investigations (Clear and Patrick 1993, Mankevičienè et al. 2006).

Our investigation showed that the high fertilizer rates may have influence on the increasing of fungal contamination on wheat grain. This agrees with the data reported by Mankevičienè et al. (2006), where the high fertilization level $\left(\mathrm{N}_{180} \mathrm{P}_{80} \mathrm{~K}_{140} \mathrm{~S}_{13}\right)$, used for conventionally grown winter wheat 'Ada', increased grain surface contamination with fungi by $75.5 \%$ compared with the unfertilized wheat. High fertilizer rates mainly increased the amount of Cladosporium fungi on the wheat grain surface. This can be explained by the investigations done by Last (1955), who has demonstrated a significant increase in spore concentration of Cladosporium spp. and some other fungi in the air in a fertilized (N, P and K) wheat crop. The influence of high fertilizer rates on grain infection with Fusarium and Penicillium fungi was significant only in separate years during our study. Previous investigations also indicate that higher fertilizer rates may increase Fusarium infection in winter wheat (Teich and Nelson 1984, Martin et al. 1991, Lemmens et al. 2004, Krnjaja et al. 2009).
Conservation tillage systems involve leaving all or part of the crop residue on the soil surface after harvest in an effort to reduce soil erosion caused by wind and water runoff (Dill-Macky and Jones 2000). However, a lot of fungal species are capable of surviving saprophytically on plant debris, which might result in an increase in the residueborne diseases of cereals. As was previously shown by Ploetz et al. (1985), in no-tillage plots the mean propagule densities of total fungi in soil were significantly higher than in the plots tilled to $15 \mathrm{~cm}$. Perello (2010) has recently reported that increasing of the foliar diseases caused by necrotrophic pathogens such as Alternaria, Cladosporium, Bipolaris, Pyrenophora and Septoria may also be due to the cultural practices such as conservation tillage, nitrogen fertilization and irrigation as well as conducive weather conditions. It was expected, that removal of the pre-crops' straw from the fields with the purpose of using it for bioenergy could help us to decrease the fungal infection in cereals. However, the obtained results indicated that notillage significantly increased fungal contamination $\left(\mathrm{cfu} \mathrm{g}^{-1}\right)$ of spring wheat grains in 2006 and 2007 and winter wheat grain infection with Alternaria (2005-2006), Aspergillus (2005) and Cladosporium (2006) species. It is likely that the residues (roots and stalks) left in the field after harvesting are still a relevant source of the fungal infection in cereals in no-tillage treatments. Since wheat precrops were pea and rape, we did not observe any significant increase in wheat pathogenic fungi such as Fusarium and others. However, Alternaria, Aspergillus and Cladosporium species may survive on a wide range of plants including pea and rape (Begum et al. 2004; Brazauskiene and Petraitiene 2006; Brazauskiene et al. 2006). On the other hand, the Verticillium longisporum and $V$. dahliae are known as Verticillium wilt causal agents of pea (Isaac and Rogers, 1974) and rape (Steventon et al. 2002) grown as pre-crops in our experiment. Small cereals are non-hosts for Verticillium pathogens. However, a greenhouse experiment showed that inoculation of wheat and barley with $V$. longisporum leads to various-degree stunting at close to the fully ripe stage (Johansson et al. 2006). During our study, Verticillium fungi were detected on the grain 


\section{Suproniene, S. et al. Tillage and fertilization effect on grain mycoflora}

surface and in the internal tissues of wheat grains. This confirms Johansson's et al. (2006) suggestions that the plant species outside the Brassicaceae can act as reservoirs of Verticillium inoculum.

Another point to be discussed is use of glyphosate in the fields. Previous glyphosate use was consistently associated with higher FHB levels, while Cochliobolus sativus, the most important common root rot pathogen, was negatively associated, with previous glyphosate use (Fernandez et al. 2009). In our study, glyphosate was used only in no-tillage treatments; however, we did not observe any increase in Fusarium infection in wheat grains.

Our findings suggest that agronomic factors are very important and may increase winter wheat grain fungal contamination. Since the residues of pre-crops were collected and removed from the experimental field and pre-crops were non-hosts for wheat pathogens during the test period, further research is needed to explore the effects of these factors on grain fungal infection level.

\section{References}

Argyris, J.,Van Sanford, D. \& TeKrony, D. 2003. Fusarium graminearum infection during wheat seed development and its effect on seed quality. Crop Science 43: 1782 - 1788.

Bailey, K.L. \& Duczek, L.J. 1995. Managing cereal diseases under reduced tillage. Canadian Journal of Plant Pathology 18: 159-167.

Bakutis, B., Baliukonienè, V. \& Lugauskas, A. 2006. Factors predetermining the abundance of fungi and mycotoxins in grain from organic and conventional farms. Ekologija 3: 122-127.

Begum, N., Alvi, K.Z., Haque, M.I., Raja, M.U. \& Chohan, S. 2004. Evaluation of mycoflora associated with pea seeds and some control measures. Plant Pathology Journal 3: 48-51.

Bogužas, V., Kairytė, A. \& Jodaugienè, D. 2010. Soil physical properties and earthworms as affected by soil tillage systems, straw and green manure management. Žemdirbystè-Agriculture 97: 3-14.

Bottalico, A., Logrieco, A. \& Visconti, A. 1989. Fusarium species and their mycotoxins in infected cereals in the field and in stored grains. In: Chelkowski J. (eds.). Fusarium Mycotoxins Taxonomy and Pathogenicity. Amsterdam: Elsevier. p. 85-119.

Bottalico, A. \& Perrone, G. 2002. Toxigenic Fusarium species and mycotoxins associated with head blight in smallgrain cereals in Europe. European Journal of Plant Pa- thology 108: 611-624.

Brazauskiene, I. \& Petraitiene, E. 2006. The occurrence of Alternaria blight (Alternaria spp.) and phoma stem cancer (Phoma lingam) on oilseed rape in central Lithuania and pathogenic fungi on harvested seed. Journal of Plant Protection Research 46: 295-311.

Brazauskienè, I., Petraitienè, E. \& Mankevičienè, A. 2006. Effects of genotype and environmental factors on rape seed contamination with mycotoxins and mycotoxin-producing fungi. Ekologija 3: 14-20.

Breitenbach, M. \& Simon-Nobbe, B. 2002. The allergens of Cladosporium herbatum and Alternaria alternata. Chemical Immunology 81: 48-72.

Bryden, W.L. 2007. Mycotoxins in the food chain: human health implications. Asia Pacific Journal of Clinical Nutrition 16: 95-101.

Clear, R.M. \& Patric, S.K. 1993. Prevalence of some seedborne fungi on soft white winter wheat seed from Ontario, Canada. Canadian Plant Disease Survey 73: 143-149.

D’Mello, J.P.F., Placinta, C.M. \& Macdonald A.M.C. 1999. Fusarium mycotoxins: a review of global implications for animal health, welfare and productivity. Animal Feed Science and Technology. 80: 183-205.

Dill-Macky, R. \& Jones, R.K. 2000. The effect of previous crop residues and tillage on Fusarium head blight of wheat. Plant diseases 84: 71-76.

Elen, O. 2003. Long-term experiments with reduced tillage in spring cereals. III. Development of leaf diseases. Crop Protection 22: 65-71.

Feiza, V., Feizienè, D., Auškalnis, A. \& Kadžienè, G. 2010. Sustainable tillage: results from long-term field experiments on Cambisol. Žemdirbystė-Agriculture 97: 3-14.

Feizienè, D., Feiza, V., Semaškienè, R. \& Kadžienè, G. 2006. Economic and energetic evaluation of winter wheat yield and grain quality potential in different soil management systems. Žemdirbysté-Agriculture 93: 65-89.

Fernandez, M.R., Zentner, R.P., Basnya,t P., Gehl, D., Selles, D. \& Huber, D. 2009. Glyphosate associations with cereal diseases caused by Fusarium spp. in the Canadian Prairies. European Journal of Agronomy 31: 133-143.

Fernandez, M.R., Selles, F., Gehl, D., DePauw, R.M. \& Zentner, R.P. 2005. Crop production factors associated Fusarium head blight in spring wheat in Eastern Saskatchewan. Crop Science 45: 1908-1916.

Gohari, A.M., Sedaghat, N., Javan-Nikkhah, M. \& SaberiRiseh, R. 2007. Mycoflora of wheat grains in the main production area in Kerman province, Iran. International Journal of Agriculture and Biology 9: 635-637.

Gomez de Ana, S., Torres-Rodriguez, J.M., Ramirez, A.A., Garsia, S.M. \& Belmonte-Soler, J. 2006. Seasonal distribution of Alternaria, Aspergillus, Cladosporium and Penicillium species isolated in homes of fungal allergic patients. Journal of Investigational Allergology and Clinical Immunology 16: 357-363.

Isaac, I. \& Rogers, W. G. 1974. Verticillium wilt of pea (Pisum sativum). Annals of Applied Biology 76: 27-35.

International Rules for Seed Testing (ISTA). 2003. Annexe to Chapter 7. Seed Health Testing Methods. Bassersdorf, Switzerland: Bassersdorf.

Johansson, A., Goud, J-K. C. \& Dixelius, C. 2006. Plant Host Range of Verticillium longisporum and Microscle- 
Vol. 20(2011): 315-326.

rotia Density in Swedish Soils. European Journal of Plant Pathology 114: 139-149.

Jørgensen, L.N. \& Olsen, L.V. 2007. Control of tan spot (Drechslera tritici-repentis) using cultivar resistance, tillage methods and fungicides. Crop Protection 26: 1606-1616.

Kačergius, A., Lugauskas, A., Levinskaitè, L., Varnaitè, T., Mankevičienè, A., Bakutis, B., Baliukonienè, V. \& Brūkštienè, D. 2005. Screening of micromycetes producing toxic substances under various conditions. Botanica Lituanica Suppl. 7: 65-75.

Kosiak, B., Torp, M., Skjerve, E. \& Thrane, U. 2007. The prevalence and distribution of Fusarium species in Norwegian cereals: a survey. Acta agriculturae Scandinavica, Section B, Soil and plant science 53: 168-176.

Krnjaja, V.S., Levic, J.T., Nešic, Z.D. \& Stankovic, S.Ž. 2009. Effects of fertilizers on winter wheat infection caused by Fusarium species. Proceedings for Natural Sciences, Matica Srpska Novi Sad. 116: 61-66.

Last, F.T. 1955. The spore content of air within and above mildew-infected cereal crops. Transactions of the British Mycological Society 38: 453-464.

Lemmens, M., Haim, K., Lew, H. \& Ruckenbauer, P. 2004. The effect of nitrogen fertilization on Fusarium Head Blight development and deoxynivalenol contamination in wheat. Journal of Phytopathology 152: 1-8.

Leslie, J.F. \& Summerell, B.A. 2006. The Fusarium Laboratory Manual. lowa, USA: Blackwell Publishing. 388 p.

Lõiveke, H., llumae, E. \& Laitamm, H. 2004. Microfungi in grain and grain feeds and their potential toxicity. Agronomy Research 2: 195-205.

Lori, G.A., Sisterna, M.N., Sarandon, S.J., Rizzo, I. \& Chidichimo, H. 2009. Fusarium head blight in wheat: Impact of tillage and other agronomic practices under natural infection. Crop protection 28: 495-502.

Lugauskas, A., Paškevičius, A. \& Repečkienè, J. 2002. Patogeniški ir toksiški mikroorganizmai žmogaus aplinkoje. Vilnius, Lietuva p. 434.

Maciorowski, K.G., Herrera, P., Jones, F.T., Pillai, S.D. \& Ricke, S.C. 2007. Effects on poultry and livestock of feed contamination with bacteria and fungi. Animal Feed Science and Technology 133: 109-136.

Malaker, P.K., Mian, I.H., Bhuiyan, K.A., Akanda, A.M. \& Reza, M.M.A. 2008. Effect of storage containers and time on seed quality of wheat. Bangladesh Journal of Agricultural Research 33: 469-477.

Malone, J.P., Muskett, A.E. \& Sheppard J.W. (eds.). 1997. Seed-Borne Fungi. Description of 77 fungus species. $3^{\text {rd }}$ edition. Zurich: ISTA. 191 p.

Mankevičienè, A., Dabkevičius, Z., Mačkinaitè,R. \& Cecevičienè, J. 2006. Contamination of winter wheat grain with fungi and mycotoxins as affected by fertilization level. Žemdirbystė-Agriculture 93: 131-140.

Martin, R.A., MacLeod, J.A. \& Caldwel, C. 1991. Influences of production inputs on incidence of infection by Fusarium species on cereal seed. Plant Disease 75: 784-788.

Mathur, S.B. \& Kongsdal, O. 2003. Common laboratory seed health testing methods for detecting fungi. Danish Govt. Institute of Seed Pathology for Developing Countries. Copenhagen, Denmark. Switzerland: ISTA. 425 p.

Nelson, P.E., Toussoun, T.A. \& Marasas, W.F.O. 1983. Fusarium Species: An Illustrated Manual for Identifica- tion. University Park and London, USA The Pennsylvania State University Press. 193 p.

Perello, A.E. 2010. New and emerging fungal pathogens associated with leaf blight symptoms on wheat (Triticum aestivum) in Argentina. In: Arya, A. \& Perello, A.E. (eds.) Management of fungal plant pathogens. Preston, UK: MPG Books Group. p. 231-244.

Pitt, J.I. 2000. Toxigenic fungi and mycotoxins. British Medical Bulletin 56: 184-192.

Ploetz, R.C., Mitchell, D.J. \& Gallaher, R.N. 1985. Population dynamics of soilborne fungi in a field multicropped to rye and soybeans under reduced tillage in Florida. Phytopathology 75: 1447-1451.

Rajput, M.A., Pathan, M.A., Lodhi, A.M., Shah, G.S. \& Khanzada, K.A. 2005. Studies on seed-borne fungi of wheat in Singh province and their effect on seed germination. Pakistan Journal of Botany 37: 177-181.

Ribera, L.A., Hons, F.M. \& Richardson, J.W. 2004. An economic comparison conventional and no-tillage farming system in Burleson country, Texas. Agronomy Journal 96: 415-424.

Roldán, A., Salinas-García, J.R., Alguacil, M.M., Díaz, G., \& Caravaca, F. 2004. Changes in soil microbial activity following conservation tillage practices in a sorghum field under subtropical conditions. In: Conserving soil and water for society: sharing solutions. Proceedings of the 13th International Soil Conservation Organization Conference in Brisbane, Australia. 687: 1- 4.

Sauer, D.B. 1988. Effects of fungal deterioration on grain: nutritional value, toxicity, germination. International Journal of Food Microbiology 7: 267-75.

Scudamore, K.A. 2000. Mycotoxins in stored grain. HGCA conference: Crop management into the Millenium. London, 6 and 7 January 2000. Paper 18, p. 18.1-18.9

Semaškienè, R., Mankevičienè, A., Dabkevičius, Z. \& Leistrumaitè, A. 2005. Toxic fungi infection and mycotoxin level in organic grain. Botanica Lithuanica 7: 17-25.

Steventon, L. A., Fahleson, J., Hu, Q. \& Dixelius, C. 2002. Identification of the causal agent of Verticillium wilt of winter oilseed rape in Sweden, V. Iongisporum. Mycological Research 106: 570-578.

Subbulakshmi, S., Harisudan, C., Saravanan, N. \& Subbian, P. 2009. Conservation Tillage - An Eco Friendly Management Practices for Agriculture. Research Journal of Agriculture and Biological Sciences 5: 1098-1103.

Suproniene, S., Justesen, A. F., Nicolaisen, M., Mankeviciene, A., Dabkevicius, Z., Semaskiene, R. \& Leistrumaite, A. 2010. Distribution of trichothecene and zearalenone producing Fusarium species in grain of different cereal species and cultivars grown under organic farming conditions in Lithuania. Annals of Agricultural and Environmental Medicine 17: 79-86.

Surai, P.F. \& Mezes, M. 2005. Mycotoxins and immunity: theoretical consideration and practical applications. Praxis veterinaria 53: 71-88.

Švedas, A. \& Tarakanovas, P. 2000. Tręšimo planavimas. Kompiuterinè versija: Tręšimas. - Akademija. 34 p.

Tarakanovas, P. \& Raudonius, S. 2003. Statistical analysis of agronomical research data using software ANOVA, STAT, SPLIT-PLOT from packet SELEKCIJA and IRRISTAT. Published by Lithuanian University of Agriculture, Akademija, LT. (in Lithuanian).

Teich, A.H. \& Nelson, K. 1984. Survey of fusarium head 


\section{AGRICULTURAL AND FOOD SCIENCE}

Suproniene, S. et al. Tillage and fertilization effect on grain mycoflora

blight and possible effects of cultural practices in wheat fields in Lambton County in 1983. Canadian Plant Disease 64: 11-13.

Teich, A.H. 1989. Epidemiology of wheat (Triticum aestivumL.) scab caused by Fusarium spp In: Chelkowski J. (eds.). Fusarium Mycotoxins Taxonomy and Pathogenicity. Elsevier, Amsterdam, p. 269-282.

Thomma, H.J. 2003. Alternaria spp.: from general saprophyte to specific parasite. Molecular plant pathology 4: 225-236.

Thrane, U., Adler, A., Clasen, P., Galvano, F., Langseth, W., Lew, H., Logrieco, A., Nielsen, K.F. \& Ritieni, A. 2004. Diversity in metabolite production by Fusarium langsethiae, Fusarium poae and Fusarium sporotrichioides. Journal of Food Microbiology 95: 257-266.

Tuite, J., Shaner, G. \& Everson, R.J. 1990. Wheat scab in soft red winter wheat in India in 1986 and its relations to some quality measurements. Plant Disease 74: 959-962.

Yalcin, H., Cakir, E. \& Aykas, E. 2005. Tillage parameters and economic analysis of direct seeding, minimum and conventional tillage in wheat. Journal of Agronomy 4: 329-332. 